\title{
Pneumocystis jirovecii Laboratuvar Tanısında Gerçek Zamanlı Polimeraz Zincir Reaksiyonu Yönteminin Değerlendirilmesi
}

\section{Evaluation of Real-Time Polymerase Chain Reaction in Pneumocystis jirovecii Laboratory Diagnosis}

\author{
Soykan ÖZKOÇ ${ }^{1}(I D)$, Ceren ERGÜDEN GÜRBÜZ¹(ID), Ayça Arzu SAYINER²(ID), \\ Songül BAYRAM DELIBAŞ ${ }^{1}(I D)$ \\ ${ }^{1}$ Dokuz Eylül Üniversitesi Tıp Fakültesi, Tıbbi Parazitoloji Anabilim Dalı, İzmir. \\ ${ }^{1}$ Dokuz Eylul University Faculty of Medicine, Department of Medical Parasitology, Izmir, Turkey. \\ ${ }^{2}$ Dokuz Eylül Üniversitesi Tıp Fakültesi, Tıbbi Mikrobiyoloji Anabilim Dalı, Tıbbi Viroloji Bilim Dalı, İzmir. \\ ${ }^{2}$ Dokuz Eylul University Faculty of Medicine, Department of Medical Microbiology, Division of Medical Virology, \\ Izmir, Turkey.
} Makale Atıfı: Özkoç S, Ergüden Gürbüz C, Sayıner AA, Bayram Delibaş S. Pneumocystis jirovecii laboratuvar tanısında gerçek
zamanlı polimeraz zincir reaksiyonu yönteminin değerlendirilmesi. Mikrobiyol Bul 2020;54(3):418-428.

\section{ÖZ}

İnsana özgül bir tür olan Pneumocystis jirovecii, immün sistemi baskılanmış kişilerde P.jirovecii pnömonisi (PCP)'ne neden olarak ölümcül enfeksiyonlara yol açmaktadır. Mikroorganizmanın tanısında direkt mikroskopi altın standart olsa da düşük P.jirovecii yükünün gözlendiği insan immün yetmezlik virüsü (HIV) dışı immünsupresif hastalarda polimeraz zincir reaksiyonu (PCR) gibi moleküler yöntemlere gereksinim duyulmaktadır. Bu çalışmada gerçek zamanlı PCR (Rt-PCR) yönteminin P.jirovecii laboratuvar tanısındaki değerinin ortaya konulması amaçlanmıştır. Dokuz Eylül Üniversitesi Hastanesi Merkez Tıbbi Parazitoloji Laboratuvarına PCP şüphesiyle gönderilen 658 hastanın bronkoalveoler lavaj (BAL) örneği çalışmaya dahil edilmiştir. BAL sIVIsı örnekleri P.jirovecii ribozomal RNA büyük alt ünitesini kodlayan mitokondriyal geni (mtLSUrRNA) çoğaltan Rt-PCR yöntemi ile değerlendirilmiştir. Tüm örneklere Giemsa ve Gomori'nin metenamin gümüş (GMG) boyaları uygulanırken Rt-PCR ile pozitif saptanan örnekler ayrıca nested-PCR (n-PCR) yöntemi ile de değerlendirilmiştir. Bu örneklerin 92 (\%14.3)'si Rt-PCR ile pozitif olarak bulunmuştur. n-PCR ile 92 hastanın 85 (\%92.4)'inde pozitiflik saptanmıştır. Mikroskobik inceleme sonucunda ise örneklerin yalnızca yedisinde P.jirovecii kist ve trofozoitlerine rastlanmıştır. Rt-PCR pozitif hastaların ortalama "cycle threshold $\left(C_{T}\right)$ " değeri $29.7\left(18.17 \leq C_{T} \leq 37.96\right)$ olarak saptanmıştır. Bu hastalardaki P.jirovecii yükü $2.6 \times 10^{1}-6.15 \times 10^{7} \mathrm{kopya} / \mathrm{ml}$ olarak hesaplanmıştır. n-PCR ile pozitif saptanan örneklerin Rt-PCR'deki $C_{T}$ değerlerinin ortalaması $\left(C_{\text {Tort }}=29.2\right)$ ile negatif bulunanların ortalaması $\left(C_{\text {Tort }}=36.7\right)$ arasındaki fark istatistiksel olarak anlamlı bulunmuştur $(\mathrm{p}<0.01)$. Mikroskopisi pozitif olan örneklerin RtPCR'deki $C_{T}$ değerlerinın sırasıyla; 18.2, 20.9, 22.2, 24.3, 24.7, 26.5, 29.7 olduğu görülmüştür. Mikroskopisi pozitif ve negatif olan örneklerin $C_{T}$ ortalamaları arasındaki fark yine istatistiksel olarak anlamlıydı $(p<$ 0.05). Pozitif bulunan hastalar tanılarına göre gruplandığında; en düşük $C_{T}$ değer ortalamasının $\left(C_{T o r t}=\right.$ 24.8) HIV pozitif hastalarda olduğu görülmüştür. Organ transplantasyonu hastaları $\left(C_{\text {Tort }}=26.15\right)$ ve kolajen-vasküler-enflamatuvar hasta grubunda $\left(C_{\text {Tort }}=27.8\right)$ saptanan $C_{T}$ değer ortalamaları diğer grup- 
lardan istatistiksel olarak anlamlı düzeyde düşük bulunmuştur. Bu çalışma, Rt-PCR'nin P.jirovecii laboratuvar tanısında etkili bir yöntem olduğunu ortaya koymuştur. Konvansiyonel n-PCR yönteminin çok düşük yoğunluktaki etken varlığında Rt-PCR'ye göre daha başarısız olduğu; direkt mikroskopinin ise genellikle etkenin yoğun olduğu örneklerde pozitif sonuç verdiği anlaşılmaktadır.

Anahtar kelimeler: Pneumocystis jirovecii; gerçek zamanlı polimeraz zincir reaksiyonu; nested-PCR; mikroskopi.

\section{ABSTRACT}

Pneumocystis jirovecii is a human-specific species and causes fatal infections like P.jirovecii pneumonia (PCP) in immunocompromised persons. Although direct microscopy is the gold standard in the diagnosis of the microorganism, molecular methods such as polymerase chain reaction (PCR) are needed in non-human immune deficiency virus (HIV) immunosuppresive patients with low P.jirovecii burden. In this study, we aimed to evaluate the value of real-time PCR (Rt-PCR) in the laboratory diagnosis of P.jirovecii. Bronchoalveolar lavage (BAL) specimens of 658 patients sent to Dokuz Eylul University Hospital Central Medical Parasitology Laboratory on suspicion of PCP were included in the study. BAL fluids were evaluated for identification of P.jirovecii mitochondrial gene coding ribosomal large subunit (mtLSUrRNA) using Rt-PCR. In addition, Giemsa and Gomori's methenamine silver (GMG) staining assays were applied to all samples and nested PCR (n-PCR) assay was applied to positive samples detected by real time PCR. Ninety-two (14.3\%) of these samples were positive by Rt-PCR. Of these 92 patients, 85 (92.4\%) were positive with n-PCR. Only seven of the specimens had P.jirovecii cysts and trophozoites with microscopic examination. The mean cycle threshold $\left(C_{T}\right)$ value of Rt-PCR positive patients was $29.7\left(18.17 \leq C_{T} \leq\right.$ 37.96). P.jirovecii load in these patients was calculated as $2.6 \times 10^{1}-6.15 \times 10^{7}$ copies $/ \mathrm{ml}$. The difference between the mean $C_{T}$ values of $n-P C R$ positive and negative results was statistically significant $(p<0.01)$. The $C_{T}$ values of Rt-PCR of the samples with positive microscopy were; 18.2, 20.9, 22.2, 24.3, 24.7, 26.5, 29.7. The difference between the $C_{T}$ means of the samples with positive and negative microscopy was statistically significant $(p<0.05)$. When positive patients were grouped according to their diagnosis; the lowest mean $C_{T}$ value $\left(C_{T \text { mean }}=24.8\right)$ was found in HIV-positive patients. On the other hand, $C_{T}$ values were found to be significantly lower in the organ transplantation patients $\left(C_{T_{\text {mean }}}=26.15\right)$ and in the collagen-vascular-inflammatory patient group $\left(C_{T \text { mean }}=27.8\right)$. This study demonstrated that Rt-PCR was the effective method in the diagnosis of P.jirovecii in the laboratory. Conventional n-PCR method was found to be more unsuccessful than Rt-PCR in the presence of very low density organism; direct microscopy is generally found to be positive in samples with a higher burden of P.jirovecii.

Keywords: Pneumocystis jirovecii; real-time polymerase chain reaction; nested-PCR; microscopy

\section{Giriş}

Pneumocystis jirovecii, bağışıklığı baskılanmış kişilerde ölümcül akciğer enfeksiyonlarına neden olabilen fırsatçı bir mikroorganizmadır ${ }^{1}$. İnsan immün yetmezlik virüsü (HIV) ile enfekte kişilerdeki P.jirovecii pnömonisi (PCP) insidansı yüksek etkinliğe sahip antiretroviral tedavi ve profilaksinin uygulamaya girmesiyle oldukça azalmış durumdadır. Ancak, yeni nesil immünsupresif tedavilerin artmasına paralel olarak, organ transplantasyonlarında, malignitelerde ve otoimmün hastalıklarda enfeksiyonun görülme sıklığı son yıllarda dramatik bir artı̧̧ göstermiştir ${ }^{2,3}$. Bu grup immünsupresif hastalarda gözlenen P.jirovecii enfeksiyonunun daha fulminan seyretmesi ve tedavi edilmediği durumlarda gözlenen \%30-50 mortalite oranları enfeksiyonun tanısını daha da önemli hale getirmektedir ${ }^{4,5}$.

P.jirovecii, diğer mantarların aksine parazitik bir yaşam şekli sergilemektedir ${ }^{1,6}$. Alveoler boşlukta tip 1 pnömositlere tutunarak yaşayan bu mikroorganizmanın şimdiye kadar başarılı bir kültürü yapılamamıştı ${ }^{1}$. Bu nedenle boyalı mikroskobik inceleme, P.jirovecii laboratuvar tanısında altın standart olarak kabul edilmektedir. Gram, Weigert ve Giemsa 
aseksüel trofik formların gösterilmesinde en sık tercih edilen boya olurken seksüel kistik formların tanısında metenamin gümüş ve toluidin boyamanın yanı sıra immünfloresan yöntemler kullanılmaktadır ${ }^{7-9}$. Diğer taraftan mikroorganizma yoğunluğunun düşük olduğu özellikle HIV dışı immünsupresif hastalarda mikroskopinin duyarlılı̆ı oldukça azalmaktadır². Etkenin mikroskobik olarak gösterilemediği bu tip hastalarda polimeraz zincir reaksiyonu (PCR) temelli moleküler yöntemlerin kullanılması önerilmektedir ${ }^{10,11}$.

Temel metabolik fonksiyonlarla ilişkili bulunan ve ribozomal RNA geniş alt ünitesini kodlayan mitokondriyal (mtLSU-rRNA) geni, P.jirovecii moleküler tanısında en sık tercih edilen genlerden biri konumundadır. Her bir mikroorganizmada aynı haplotipte birçok mitokondri bulunmasından dolayı bu gen bölgesi P.jirovecii tanısında ve kantitasyonunda tek kopyalı genlere göre daha başarılı bulunmuştur ${ }^{12-14}$. Bu çalışmada, P.jirovecii rutin tanısında kullandığımız P.jirovecii gerçek zamanlı PCR (Rt-PCR) yönteminin tanısal değerlerinin ortaya konulması amaçlanmıştır.

\section{GEREÇ ve YÖNTEM}

Bu çalışma, Dokuz Eylül Üniversitesi Tıp Fakültesi Girişimsel Olmayan Araştırmalar Etik Kurulu onayı ile gerçekleştirildi (Tarih: 05.05.2016 ve Karar no: 2016/12-28).

\section{Hasta Örneklerinin Toplanması ve İşlenmesi}

Haziran 2011-Temmuz 2019 tarihleri arasında farklı pulmoner semptomları nedeniyle bronkoskopi yapılan P.jirovecii tanısı düşünülerek Dokuz Eylül Üniversitesi Hastanesi Tıbbi Parazitoloji Merkez Laboratuvarına gönderilen 658 hastanın klinik örneği çalışmaya dahil edildi. Hastane ve laboratuvar bilgi sistemi üzerinden hastalara ait bilgiler kayıt altına alındı. Hastaların bronkoalveoler lavaj (BAL) sıvısı örnekleri; boyama yöntemleri (Giemsa, Metenamin gümüş) ve moleküler yöntemin uygulanması amacıyla iki kısma ayrıldı. Nükleik asit izolasyonu için $600 \mu \mathrm{l}$ BAL sıvısı kullanıldı. EZ1 virüs mini kit (kat no: 955134) (Qiagen, Fransa) ile üretici firma önerileri doğrultusunda elde edilen ekstratlar yöntem uygulanıncaya kadar $-20^{\circ} \mathrm{C}^{\prime}$ de saklandı.

\section{Boyalı Örneklerin Hazırlanması ve Mikroskobik Değerlendirme}

Örnekler 4000 rpm'de 10 dakika santrifüj edildikten sonra her bir boyama yöntemi için iki adet preparat hazırlandı. Hazırlanan preparatlar Giemsa ve metenamin gümüş (kat no: 04-043822) (Bio Optica, Milano, İtalya) ile boyandıktan sonra 1000x büyütmede ışık mikroskobu altında incelendi ${ }^{15}$.

\section{Gerçek Zamanlı PCR (Rt-PCR)}

Rt-PCR için ticari FTD P.jirovecii (kat no: FTD-27-32) (Fast Tract Diagnostic, Lüksemburg) kiti kullanıldı. P.jirovecii mtLSU-rRNA gen bölgesi hedefleyen kit içeriğinde; pozitif kontrol olarak P.jirovecii plazmit, negatif kontrol, primerler, çift etiketli problar ve internal kontrol (Equine arterit virüs) yer almaktaydı. Amplifikasyon, revers transkripsiyon basamağını takiben aynı tüp içinde RotorGene $6000 \mathrm{Q}$ (Qiagen, Almanya) cihazında üretici firma önerilerine göre çalısıldı. PCR inhibisyonu internal kontrol ile değerlendirildi $\left(C_{T}<33\right)$. Izolasyon aşamasında 
örneklere eklenen internal kontrol ile yöntem kontrolü yapıldı. Pozitif örneklerdeki göreceli P.jirovecii kantitasyonu kit önerilerinde belirtilen aşağıda verilen formüle göre hesaplandı.

$$
\mathrm{x}=\mathrm{e}^{[(\mathrm{y}-42.347) /-1.348]}
$$

( $X=$ Gen Kopya/ml, $Y=$ Örneğin $C_{T}$ değeri; $C_{T}=$ cycle threshold, $\mathrm{e}=2.718$ )

\section{Nested-PCR (n-PCR)}

n-PCR yöntemi yalnızca Rt-PCR pozitif saptanan örneklere uygulandı. Bu yöntemde de yine Rt-PCR yönteminde olduğu gibi P.jirovecii mtLSU-rRNA gen bölgesi hedeflendi. Birinci PCR döngüsünde PAZ102-E (5'-GAT GGC TGT TTC CAA GCC CA-3') ve pAZ102 H (5'-GTG TAC GTT GCA AAG TAC TC-3') primerleri; ikinci PCR döngüsünde ise pAZ102-X (5'-GTG AAA TAC AAA TCG GAC TAG G-3') ve pAZ102-Y (5'-TCA CTT AAT ATT AAT TGG GGA GC-3') primerleri kullanıldı ${ }^{10}$. Her bir reaksiyon için $2.5 \mu \mathrm{l} 10 x$ reaksiyon tamponu, $2.5 \mu \mathrm{MgCl}_{2}$ (25 mM stok çözelti), $2.5 \mu \mathrm{l}$ dNTP (2 mM stok çözelti ), $1 \mu \mathrm{l}$ Taq DNA polimeraz ( $1 \mathrm{U} / \mu$ l stok çözelti), $0.75 \mu$ l primer $(10 \mu \mathrm{M}$ stok çözelti) ve $1 \mu$ l DNA örneği eklendikten sonra steril distile su ile son hacim $25 \mu l^{\prime}$ ye tamamlandı. Amplifikasyon, $94^{\circ} \mathrm{C}^{\prime}$ de 5 dakikalık ön denatürasyonun ardından 40 döngü; $94^{\circ} \mathrm{C}^{\prime}$ de 1 dakika, $56^{\circ} \mathrm{C}^{\prime}$ de 1 dakika, $72^{\circ} \mathrm{C}^{\prime}$ de 1.5 dakika ve son uzama basamağı için $72^{\circ} \mathrm{C}^{\prime}$ de 5 dakika olacak şekilde düzenlendi ${ }^{10,15}$. Her iki döngü için aynı miktar ve süreler uygulandı. Reaksiyon sonunda $10 \mu$ l PCR ürünü, \%1.5'lik agaroz jelde 100 volt altında 40 dakika agaroz jelde elektroforezde yürütüldükten sonra $1 \mu \mathrm{g} / \mathrm{ml}$ etidyum bromür ile boyanarak ultraviole ışık altında görüntülendi. n-PCR sonunda 267 baz çifti (bp) uzunluğunda amplikon saptanması durumunda örnekler pozitif olarak değerlendirildi.

\section{İstatistiksel Analiz}

Çalışmanın istatistiksel analizleri SPSS 15.0 programı ile yapıldı. Karşılaştırılan grupIarın analizinde student-t testinin yanı sıra Mann-Whitney $U$ ve Fisher's Exact testleri kullanıldı. $p<0.05$ değeri istatistiksel olarak anlamlı kabul edildi.

\section{BULGULAR}

Çalışmamızda Rt-PCR kiti ile hastaların \%14.3'ünde (92/644) pozitiflik saptanmıştır (Şekil 1). Bu hastaların 38 (\%41.3)'inin kadın, 54 (\%58.7)'ünün erkek, yaş aralığının ise 4-91 (ortalama 57.2) arasında olduğu tespit edilmiştir. Rt-PCR testlerinde kullanılan pozitif kontrollerin ortalama $C_{T}$ değeri $25.19\left(3.9 \times 10^{5} \mathrm{kopya} / \mathrm{ml}\right)$ bulunurken; pozitif hastaların ortalama $C_{T}$ değeri $29.7\left(18.17 \leq C_{T} \leq 37.96\right)$ olarak saptanmıştır. Hastalardaki P.jirovecii yükü ise $2.6 \times 10^{1}-6.15 \times 10^{7} \mathrm{kopya} / \mathrm{ml}$ olarak hesaplanmıştır. Kadın ve erkek hastalar arasında; yaş, $C_{T}$ değerleri ve P.jirovecii yükü açısından istatistiksel bir anlamlılık saptanmamıştır ( $p>0.05)$.

Konvansiyonel n-PCR yöntemi ise Rt-PCR ile pozitif saptanan 92 hastanın 85 (\%92.4)'inde pozitif sonuç vermiştir (Şekil 2). n-PCR ile saptanamayan yedi örneğin RtPCR'deki $C_{T}$ değerlerinin ortalaması $\left(C_{\text {Tort }}=36.7\right)$ ile pozitif olanların ortalaması $\left(C_{\text {Tort }}=\right.$ 29.2) arasındaki fark istatistiksel olarak anlamlı bulunmuştur $(p<0.01)$. 


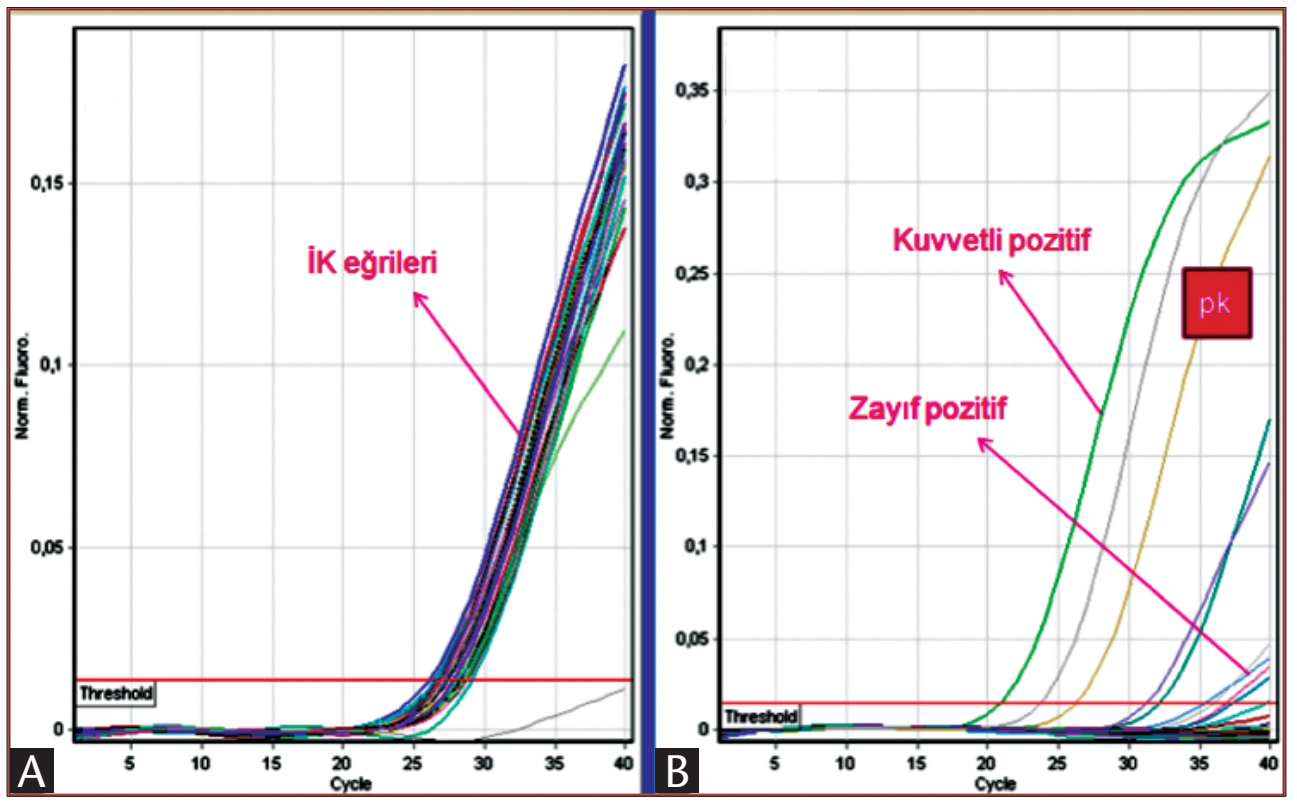

Şekil 1. Çalışılan örnek grubundan bir kısmının Rt-PCR için RotorGene 6000Q (Qiagen) cihazında kantitasyon analizi (A) Internal kontrol-ik eğrileri; (B) Çalısılan örnekler; pk: pozitif kontrol.

Diğer taraftan; mikroskobik inceleme sonucunda sadece 7 (\%0.8) hasta örneğinde P.jirovecii kist ve trofozoitleri saptanabilmiştir (Şekil 3). Mikroskopisi pozitif olan örneklerin tümü her iki PCR yöntemi ile de pozitif olarak saptanırken, Rt-PCR'deki $C_{T}$ değerleri sırasıyla; 18.2, 20.9, 22.2, 24.7, 24.3, 26.5, 29.7 olarak bulunmuştur. Mikroskopisi pozi-

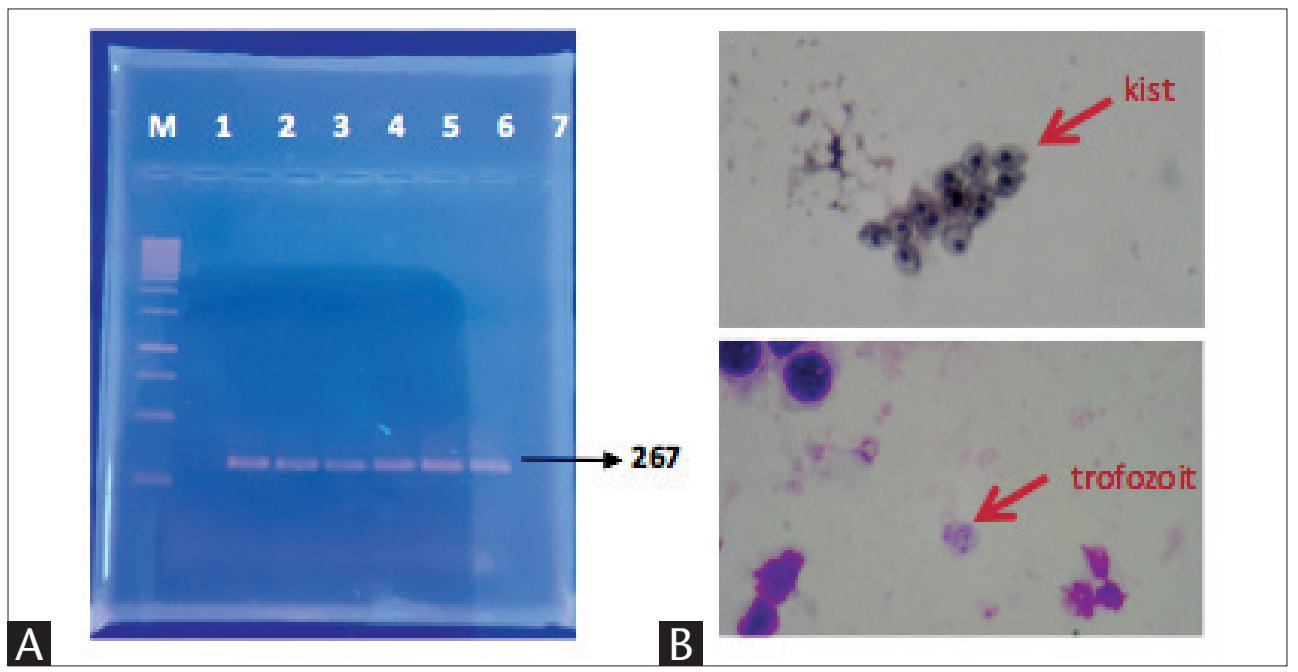

Şekil 2. A. n-PCR jel görüntüsü. M: Moleküler ağırlık standardı (1 kb), 1: Negatif kontrol, 2: Pozitif kontrol, 3-7: Pozitif hasta örnekleri. B. Metenamin gümüş ile boyanmış P.jirovecii kistleri (üst); Giemsa ile boyanmış P.jirovecii trofozoitleri (alt). 
tif ve negatif olan örneklerin $\mathrm{C}_{T}$ ortalamaları arasındaki fark yine istatistiksel olarak anlamlı bulunmuştur $(p<0.05)$.

P.jirovecii saptanan olguların gönderildikleri birimlerdeki tanılarına göre sayısal dağılımı; hematolojik maligniteler $(n=18)$, organ transplantasyonları $(n=17)$, kolajen-vasküler-enflamatuvar hastalıklar $(n=12)$, solid organ maligniteleri $(n=9)$, HIV pozitifliği olanlar $(n=3)$ şeklindeydi. Altta yatan başka bir hastalığı (örn. diabetes mellitus, kronik obstrüktif akciğer hastalığı, kalp yetmezliği vb.) olan veya yalnız tanısal amaçla bronkoskopi yapılan hastaların (örn. pnömoni etiyolojisi vb.) sayısı ise 33 olarak belirlenmiştir. Her bir grup, Rt-PCR $C_{T}$ değerleri ve parazit yükü yönünden değerlendirildiğinde organ transplantasyonu hastalarında $\left(C_{\text {Tort }}=26.15\right)$, kolajen doku ve enflamatuvar hastalığı olanlarda $\left(C_{\text {Tort }}=27.8\right)$ ve HIV pozitif hastalarda $\left(C_{T o r t}=24.8\right) C_{T}$ değerleri ve parazit yükü (kopya sayısı/ml) yönünden diğer gruplara göre istatistiksel olarak anlamlı bir farklılık saptanmıştır (Şekil 4). Hasta gruplarına ait mikroskopi, n-PCR ve Rt-PCR sonuçları Tablo I'de verilmiştir.

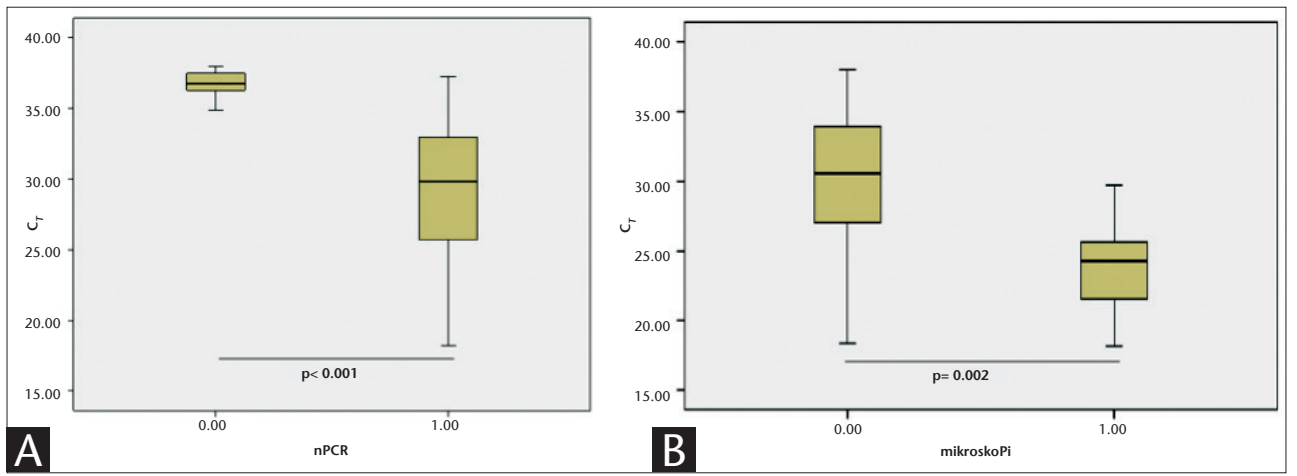

Şekil 3. A. n-PCR sonucu pozitif (1) ve negatif (0) olan hastaların $C_{T}$ karşılaştırmaları, B. Mikroskopisi pozitif (1) ve negatif ( 0 ) olan hastaların $C_{T}$ karşılaştırmaları.

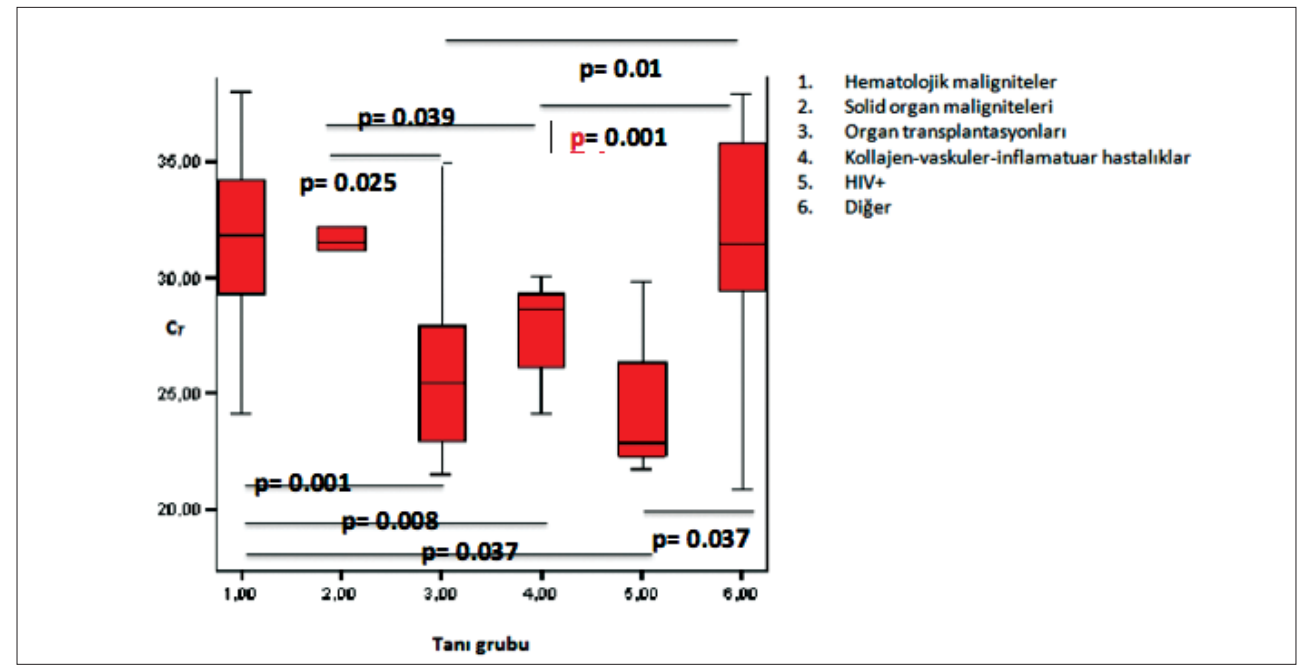

Şekil 4. Farklı hasta gruplarındaki Rt-PCR sonuçlarının karşılaştırılması. 


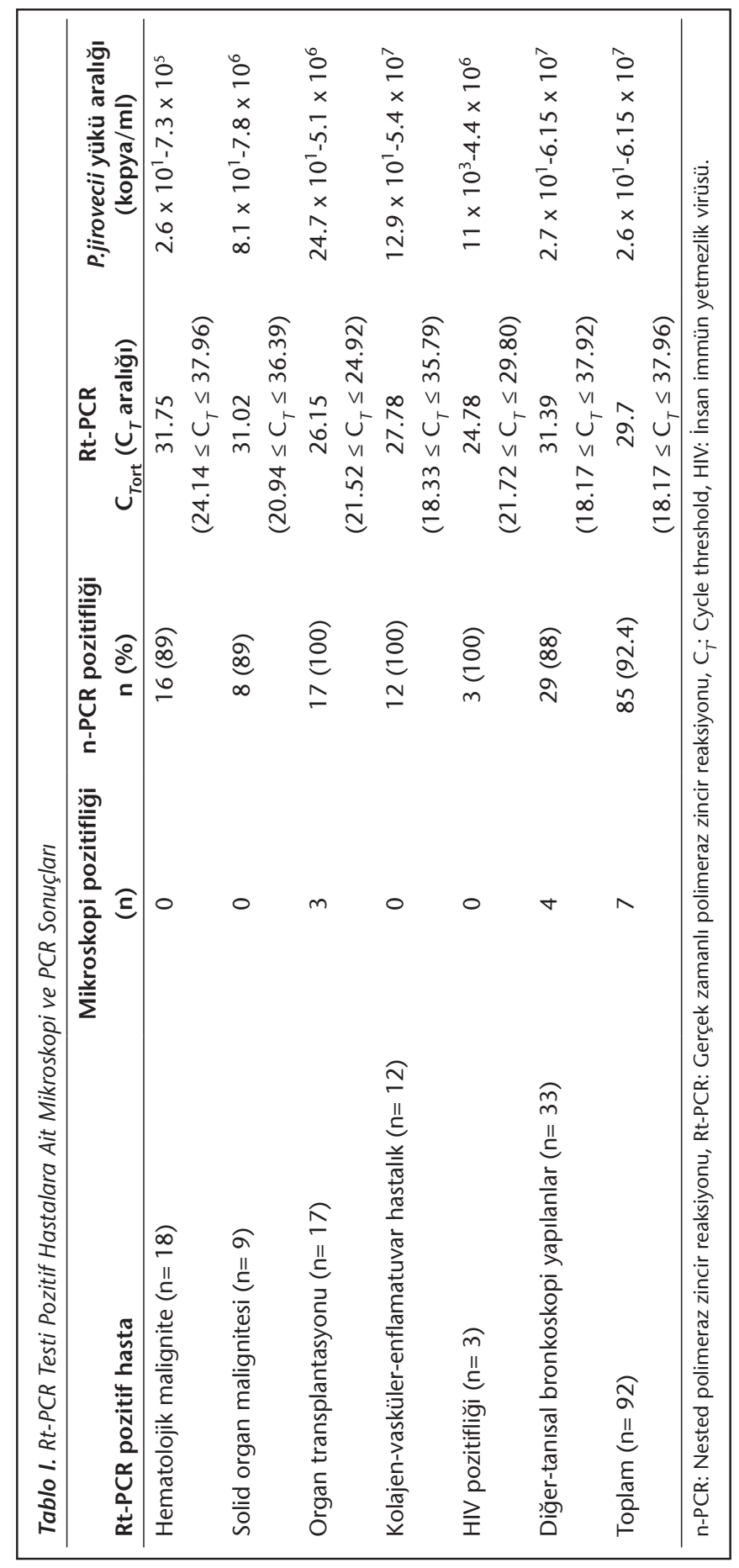




\section{TARTIŞMA}

PCP enfeksiyonunda çok farklı klinik ve radyolojik bulgular gözlenebildiğinden tanıda mutlaka etkenin kendisinin veya DNA'sının gösterilmesi gerekmektedir ${ }^{9,16}$. Örneğin, HIV pozitif olgularda ateş, kuru öksürük ve dispne gibi bulgular ön plandayken, HIV dışı immünsupresif hastalarda enfeksiyon daha ani başlangıçlı olabilmekte ve hızla solunum yetmezliğine giderek kötü prognoz sergileyebilmektedir ${ }^{5,17}$. Yine radyolojik olarak özellikle yüksek çözünürlüklü bilgisayarlı tomografilerde saptanan buzlu cam görüntüsü bazı olgularda görülmeyebilmekte hatta multinodüler yapılar, kavitasyon odakları ve kistik yapılar gibi atipik görüntüler ortaya çıkabilmektedir ${ }^{18,19}$. Diğer taraftan etkenin DNA'sının saptanması da tek başına anlamlı değildir. Klinik ve radyolojik bulguları olmayan hastalarda sadece etken DNA'sının gösterilmesi "P.jirovecii kolonizasyonu" olarak tanımlanmaktadır $^{16,20}$. Tüm bu nedenlerle PCP tanısında klinik ve laboratuvarın multidisipliner bir yaklaşım sergilemesi gerekmektedir.

P.jirovecii kültürde üretilemediğinden direkt mikroskopi uzun zaman tanıda altın standart olarak kullanılmıştır. Farklı disiplinlerde yayımlanmış birçok rehbere göre de "kesin PCP" denilebilmesi için P.jirovecii'nin mikroskobik olarak gösterilmesi gereklidir ${ }^{5,16,21}$. Ancak mikroskopinin duyarlılığı etken yükünün düşük olduğu HIV dışı immünsupresif hastalarda çoğu zaman tatmin edici değildir ${ }^{9}$. Çalışmamızda da Rt-PCR ile pozitif olan 92 örneğin yalnız yedisinde mikroskobik tanı konulabilmiştir. Mikroskopisi pozitif olan örneklerin Rt-PCR sonucundaki $C_{T}$ değer ortalaması, negatif saptanan örneklerinkinden istatistiksel olarak anlamlı düşük bulunmuştur $(p<0.05)$. Bu sonuç mikroskobik incelemenin genellikle etken yoğunluğunun fazla olduğu örneklerde başarılı olduğunu göstermiştir. Bu nedenle mikroskopinin P.jirovecii tanısında tek başına kullanılmasının birçok pozitif olgunun atlanmasına neden olacağı düşüncesindeyiz. Diğer taraftan çalışmanın dikkat çekici sonuçlarından biri de $C_{T}$ değeri düşük olan örneklerin birçoğunda mikroskopi sonucunun negatif bulunmasıydı. $C_{T}$ değeri 18.33 (kopya sayısı $5.4 \times 10^{7} / \mathrm{ml}$ ) olan bir örneğin yanı sıra HIV pozitif üç hastanın örneklerinde de P.jirovecii kist veya trofozoitleri saptanamamıştır. Bu durum bazı hastalar için önceden başlanmış ampirik tedavilerin etkeni morfolojik olarak parçalamasıyla açıklanabilir. Bununla birlikte personel deneyimine bağlı olarak preparatların hazırlanması ve boyanması aşamalarında standardizasyon probleminin yaşanmış olabilmesi de duyarlılığı düşüren olası bir diğer faktör olabilir.

P.jirovecii'nin laboratuvar tanısında moleküler yöntemler son derece önemli bir yere sahiptir ${ }^{6,11}$. Konvansiyonel PCR yöntemleri, başlangıçta mikroskopinin duyarlılık sorununu iyileştirmek için kullanılmış olsa da günümüzde daha çok genotiplendirme gibi epidemiyolojik çalışmaların bir basamağı olarak tercih edilmektedir ${ }^{12-14,16}$. Rutin tanıda ise daha çok Rt-PCR yöntemi gibi daha gelişmiş yöntemlerin kullanımı önerilmektedir. Kantitasyon olanağı sunması nedeniyle kolonizasyon/enfeksiyon ayrımında fikir veriyor olması yöntemin birincil üstünlüğü olarak gösterilmektedir ${ }^{22-24}$. Uygulamasının kolay ve hızlı bir yöntem olmasının yanı sıra kapalı sistem olması nedeniyle dışarıdan kontaminasyon riskini en aza indirmesi, yöntemin diğer avantajları olarak öne çıkmaktadır ${ }^{8,22,23,25-27}$. 
Çalışmamızda Rt-PCR yönteminin oldukça duyarlı bir yöntem olduğu görülmüştür. Yöntem, $2.6 \times 10^{1} \mathrm{kopya} / \mathrm{ml}$ gibi düşük yoğunluktaki örneklerde bile başarlı sonuç vermiştir. Konvansiyonel n-PCR yönteminin ise Rt-PCR pozitif olguların \%92.4 (85/92)'ünde pozitif saptandığı; çok düşük yoğunluktaki etken varlığında negatif sonuç verebildiği görülmüştür. n-PCR ile saptanamayan yedi örneğin Rt-PCR'deki $C_{T}$ değerlerinin ortalaması $\left(C_{\text {Tort }}=\right.$ 36.7) istatistiksel olarak anlamlı bir şekilde daha yüksek bulunmuştur $(p<0.01)$. Bununla birlikte çalısmamızın en önemli kısıtııı̆ı n-PCR yönteminin yalnız Rt-PCR'de pozitif saptanan hastalara uygulanabilmesidir. Bu nedenle, yöntemlerin özgüllük ve duyarlılık değerlerinin hesaplanmasından çok oransal olarak karşılaştırma yapılması uygun bulunmuştur.

Günümüze kadar yapılan Rt-PCR çalışmalarında $C_{T}$ ortalamaları veya P.jirovecii yükü (kopya sayısı/ml) açısından yapılan karşılaştırmalı değerlendirmelerin genellikle PCP/ kolonizasyon olguları veya HIV pozitif/HIV dışı immünsupresif gruplar arasında yapılan çalışmalar olduğu görülmektedir ${ }^{22-24,26,28}$. Bu çalışmalarda genel olarak ortak bulunan sonuç; PCP hastalarında kolonize olgulara göre, HIV pozitif hastalarda da HIV dışı immünsupresif gruplara göre parazit yükünün daha yüksek olduğudur ${ }^{11,23,25,28}$. Çalışmamızda farklı hasta grupları göreceli olarak parazit yükü yönünden değerlendirilmiştir. Öncelikli değerlendirmede kadın ve erkek hastalar arasında P.jirovecii yükü açısından anlamlı bir fark saptanmamıştır. Çalışmamızda her ne kadar yalnız üç HIV pozitif hasta bulunuyor olsa da bu grupta literatüre uyumlu olarak en yüksek P.jirovecii yükü saptanmıştır $\left(\mathrm{C}_{\text {Tort }}=\right.$ 24.78). Çalışmamızda olguları PCP pnömonisi (kesin/olası) veya kolonizasyon diye klinik olarak tanımlama yapma olanağı bulunamamışıtır. Buna rağmen HIV dışı immünsupresif grup hastalar, kendi içinde dört farklı kategoride değerlendirilmiştir. Bu değerlendirme sonucunda organ transplantasyonu hastaları ve kolajen-vasküler-enflamatuvar hastalığı olan HIV dışı immünsupresif gruptaki P.jirovecii yük ortalamaları hematolojik maligniteler ve solid organ tümörlerine göre daha fazla bulunmuştur (Tablo I). Bu sonuç, HIV dışındaki immünsupresif hastaların da kendi içinde farklılıklar gösterebildiğini ortaya koymaktadır. Bu durumun PCP pnömonisi veya kolonizasyonu olma durumundan çok bu gruplarda kullanılan immünsupresif ilaçların yarattığı immün baskılamanın doğasından kaynaklandığı düşünülmüştür. Diğer taraftan tanısal amaçlı bronkoskopi yapılan hastalarda gözlenen düşük $\mathrm{C}_{\text {Tort }}$ değerinin ise, daha çok kolonizasyon olarak değerlendirilebileceği kanısı doğmuştur.

Çalışmada kullanmış olduğumuz FTD-P.jirovecii Rt-PCR kiti, iyi laboratuvar uygulamaları rehberine uygun bir in vitro diagnostik test konumundadır ${ }^{29}$. Kit içeriğinde standart bir DNA bulunmadığından gerçek bir kantitasyon yapma şansı bulunmamaktadır. Ancak üretici firmanın kantitasyon formülasyonu üzerinden hedef bölge kopya sayısı hesaplanarak göreceli bir kantitasyon imkanı sağlanmıştır. Hoauro ve arkadaşları FTD-P.jirovecii kitini değerlendirdikleri çalışmada ${ }^{24}$ PCP hastaları ve kolonize hastalar için ortanca kopya sayılarının sırasıyla $1.35 \times 10^{8} / \mathrm{ml}$ ve $1.45 \times 10^{5} / \mathrm{ml}$ olarak saptamışlardır. Aynı çalışmada, $C_{T}: 22$ ve $C_{T}: 25$ değerleri $\mathrm{PCP} /$ kolonizasyon ayrımında alt ve üst cut-off değerleri olarak belirlenmiştir. Çalışmamızda FTD-P.jirovecii kiti ile pozitif olan 92 hastanın BAL sıvılarındaki en yüksek kopya sayısı $6.15 \times 10^{7} / \mathrm{ml}$ olarak saptanmıştır. Her ne kadar PCP ve kolonize 
hastaları tam olarak ayırmamış olsak da testin çalışma grubundan elde edilecek cut-off

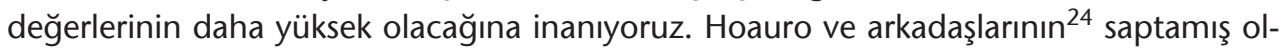
dukları düşük cut-off değerleri çalışma gruplarının az sayıda hasta içeriyor olması ve yedi HIV'lı PCP hastasının bulunmasından kaynaklanıyor olabilir.

Bu çalışma, P.jirovecii laboratuvar tanısında Rt-PCR yönteminin son derece duyarlı bir yöntem olduğunu ortaya koymuştur. Konvansiyonel n-PCR yönteminin çok düşük yoğunluktaki etken varlığında negatif sonuç verebildiği görülürken direkt mikroskopinin ise daha çok etkenin yoğun olduğu örneklerde başarılı olduğu anlaşılmaktadır. Diğer taraftan Rt-PCR yönteminin göreceli bir kantitasyon yapma olanağı sunması, klinik kararın verilmesinde ve tedavi yanıtının izleminde katkı sağlayabilir. Klinik tanıları netleşmiş olan; kesin PCP, olası PCP ve kolonize hastaların örnekleri üzerinde yapılacak çalışmalar ile testlerin cut-off değerlerini belirlemek P.jirovecii tanısını koymanın yanı sıra klinisyenlere PCP/kolonizasyon ayrımında da yol gösterici olabileceği kanaatindeyiz.

\section{ETIK KURUL ONAYI}

Bu çalışma, Dokuz Eylül Üniversitesi Tıp Fakültesi Girişimsel Olmayan Araştırmalar Etik Kurulu onayı ile gerçekleştirildi (Tarih: 05.05.2016 ve Karar no: 2016/12-28).

\section{ÇIKAR ÇATIŞMASI}

Yazarlar bu makale ile ilgili herhangi bir çıkar çatışması bildirmemişlerdir.

\section{KAYNAKLAR}

1. Otieno-Odhiambo P, Wasserman S, Hoving JC. The contribution of host cells to Pneumocystis immunity: An update. Pathogens 2019; 8(2): 52.

2. Tasaka S, Tokuda H. Pneumocystis jirovecii pneumonia in non-HIV-infected patients in the era of novel immunosuppressive therapies. J Infect Chemother 2012; 18(6): 793-806.

3. Roux A, Gonzalez F, Roux M, Mehrad M, Menotti J, Zahar JR, et al. Update on pulmonary Pneumocystis jirovecii infection in non-HIV patients. Med Mal Infect 2014; 44(5): 185-98.

4. Tasaka S. Recent advances in the diagnosis and management of Pneumocystis pneumonia. Tuberc Respir Dis 2020; 83(2): 132-40.

5. Cordonnier C, Alanio A, Cesaro S, Maschmeyer G, Einsele H, Donnelly P, et al. Pneumocystis jiroveciipneumonia: still a concern in patients with haematological malignancies and stem cell transplant recipients-authors> response. J Antimicrob Chemother 2017; 72(4): 1266-8.

6. Delliere S, Gits-Muselli M, Bretagne S, Alanio A. Outbreak-causing fungi: Pneumocystis jirovecii. Mycopathologia 2019; Nov 28.

7. Song Y, Ren Y, Wang X, Li R. Recent advances in the diagnosis of Pneumocystis pneumonia. Med Mycol J 2016; 57: 111-6.

8. Töz S, Gündüz C, Tetik A, Taşbakan M, Pullukçu H, Bacakoğlu F, et al. The comparison of microscopy and real time polymerase chain reaction methods for the diagnosis of Pneumocystis jirovecii pneumonia: evaluation of clinical parameters. Tuberk Toraks 2017; 65(3): 220-6.

9. White PL, Backx M, Barnes RA. Diagnosis and management of Pneumocystis jirovecii infection. Expert Rev Anti Infect Ther 2017; 15: 435-47.

10. Tia T, Putaporntip C, Kosuwin R, Kongpolprom N, Kawkitinarong K, Jongwutiwes S. A highly sensitive novel PCR assay for detection of P.jirovecii DNA in bronchoalveloar lavagespecimens from immunocompromised patients. Clin Microbiol Infect 2012; 18(6): 598-603. 
11. Doyle L, Vogel S, Procop GW. Pneumocystis PCR: it is time to make PCR the test of choice. Open Forum Infect Dis 2017; 4: 4.

12. de Armas Y, Friaza V, Capo V, Durand-Joly I, Govín A, de la Horra C, et al. Low genetic diversity of Pneumocystis jirovecii among Cuban population based on two-locus mitochondrial typing. Med Mycol 2012; 50(4): 417-20.

13. Monroy-Vaca EX, de Armas Y, Illnait-Zaragozi MT, Torano G, Diaz R, Vega D, et al. Prevalence and genotype distribution of Pneumocystis jirovecii in Cuban infants and toddlers with whooping cough. J Clin Microbiol 2014; 52(1): 45-51.

14. Dimonte S, Berrilli F, D'Orazi C, D'Alfonso R, Placco F, Bordi E, et al. Molecular analysis based on mtLSU-rRNA and DHPS sequences of Pneumocystis jirovecii from immunocompromised and immunocompetent patients in Italy. Infect Genet Evol 2013; 14: 68-72.

15. Özkoç S, Bayram Delibaş S. Investigation of Pneumocystis jirovecii pneumonia and colonization in iatrogenically immunosuppressed and immunocompetent patients. Mikrobiyol Bul 2015; 49(2): 221-30.

16. Calderon EJ, Dei-Cas E. Pneumocystis infection: unraveling the colonization-to-disease shift. Expert Rev Anti Infect Ther 2010; 8(3): 259-62.

17. Festic E, Gajic O, Limper AH, Aksamit TR. Acute respiratory failure due to Pneumocystis pneumonia in patients without human immunodeficiency virus infection: outcome and associated features. Chest 2005; 128(2): 573-9.

18. Salzer HJF, Schäfer G, Hoenigl M, Günther G, Hoffmann C, Kalsdorf B, et al. Clinical, diagnostic, and treatment disparities between HIV-Infected and non-HIV-Infected immunocompromised patients with Pneumocystis jirovecii pneumonia. Respiration 2018; 96(1): 52-65.

19. Cereser L, Dallorto A, Candoni A, Volpetti S, Righi E, Zuiani C, et al. Pneumocystis jirovecii pneumonia at chest high-resolution computed tomography (HRCT) in non-HIV immunocompromised patients: Spectrum of findings and mimickers. Eur J Radiol 2019; 116: 116-27.

20. Morris A, Norris KA. Colonization by Pneumocystis jirovecii and its role in disease. Clin Microbiol Rev 2012; 25(2): 297-317.

21. Alanio A, Hauser PM, Lagrou K, Melchers WJ, Helweg-Larsen J, Matos O, et al. ECIL guidelines for the diagnosis of Pneumocystis jirovecii pneumonia in patients with haematological malignancies and stem cell transplant recipients. J Antimicrob Chemother 2016; 71(9): 2386-96.

22. Maillet M, Maubon D, Brion JP, François P, Molina L, Stahl JP, et al. Pneumocystis jirovecii (Pj) quantitative PCR to differentiate Pj pneumonia from Pj colonization in immunocompromised patients. Eur J Clin Microbiol Infect Dis 2014; 33(3): 331-6.

23. Fauchier T, Hasseine L, Gari-Toussaint M, Casanova V, Marty PM, Pomares C. Detection of Pneumocystis jirovecii by quantitative PCR to differentiate colonization and pneumonia in Immunocompromised HIVpositive and HIV-negative patients. J Clin Microbiol 2016; 54(6): 1487-95.

24. Hoarau G, Le Gal S, Zunic P, Poubeau P, Antok E, Jaubert J, et al. Evaluation of quantitative FTD-Pneumocystis jirovecii kit for Pneumocystis infection diagnosis. Diagn Microbiol Infect Dis 2017; 89(3): 212-7.

25. Larsen HH, Masur H, Kovacs JA, Gill VJ, Silcott VA, Kogulan P, et al. Development and evaluation of a quantitative, touch-down, real-time PCR assay for diagnosing Pneumocystis carinii pneumonia. J Clin Microbiol 2002; 40(2): 490-4.

26. Alanio A, Desoubeaux G, Sarfati C, Hamane S, Bergeron A, Azoulay E, et al. Real-time PCR assaybased strategy for differentiation between active Pneumocystis jirovecii pneumonia and colonization in immunocompromised patients. Clin Microbiol Infect 2011; 17(10): 1531-7.

27. Unnewehr M, Friederichs H, Bartsch P, Schaaf B. High diagnostic value of a new real-time pneumocystis PCR from bronchoalveolar lavage in a real-life clinical setting. Respiration 2016; 92(3): 144-9.

28. Fillaux J, Malvy S, Alvarez M, Fabre R, Cassaing S, Marchou B, et al. Accuracy of a routine real-time PCR assay for the diagnosis of Pneumocystis jirovecii pneumonia. J Microbiol Methods 2008; 75(2): 258-61.

29. Bustin SA, Benes V, Garson JA, Hellemans J, Huggett J, Kubista M, et al. The MIQE guidelines: minimum information for publication of quantitative real-time PCR experiments. Clin Chem 2009; 55(4): 611-22. 